\title{
Brazil and Japan give fuel to ethanol market
}

Rising oil prices and apprehension about global warming are prompting governments to rethink their energy supply policies. Brazil has recently carried out negotiations with Japan to export ethanol produced from sugarcane. That's comes after Japan authorized the substitution of up to $3 \%$ of gasoline with ethanol to help meet its Kyoto Treaty commitments. Indeed, burning ethanol recycles atmospheric carbon instead of releasing fossilized carbon into the atmosphere, thus reducing the accumulation of greenhouse gases. The consequent increase in demand will test the feasibility of establishing sustainable industrial biotech activity in the country. This may also stimulate other countries to emulate this strategy to make their entry onto the industrial biotech scene.

A deal between the Japanese government and Brazil's Ministry for Development, Industry and Foreign Trade regarding technical cooperation and information exchange on ethanol is currently in negotiations. Meanwhile, the Brazilian national oil company Petrobras of Rio de Janeiro announced the formation of a joint venture, called Nippaku Ethanol, with Nippon Alcohol Hanbai (NAH), to export ethanol to Japan, beginning in December 2005. The tieup follows months of contacts between Brazil's Agriculture Ministry in São Paulo and the Japan Bank for International Cooperation in Tokyo, which focused on the infrastructure required to guarantee a reliable supply of ethanol.

"Exports [to Japan] will start in 2008 with 20 million liters," says João Paes de Carvalho, director, Brazilian association of biotech companies, in Rio de Janeiro. “To substitute 3\% of Japan's gasoline would require 1.8 billion liters of ethanol. As the agreement envisages a staged introduction of exports, there will be time for several new plants to be up and running. The fact that NAH is already responsible for $70 \%$ of ethanol distribution in Japan will obviously help," he adds.

Clearly what gives Brazil its competitive advantage to attract Japan as a customer for its ethanol is the head start that the country has after developing its ethanol program over the past thirty years. Brazil's national ethanol program (PROALCOOL) was originally a response to the oil shocks of the 1970s and succeeded in reducing the country's dependence on fossil fuels. Ethanol now accounts for around $40 \%$ of Brazil's driving fuel. And the country's flex fuel car fleet is the only one in the world that can use $100 \%$ of either ethanol or gasoline. In the process, Brazil has become the world's second largest producer of ethanol after the US with 15.9 billion liters in 2005, more than a third of global production.

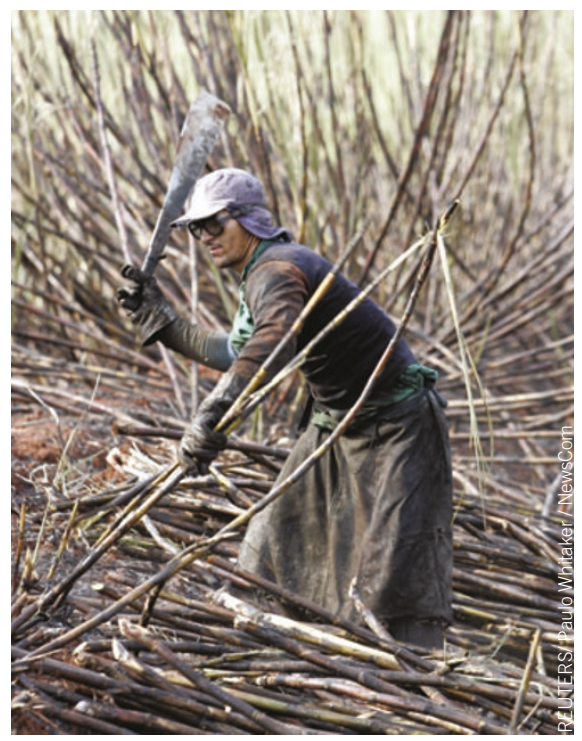

Brazil's ability to produce high volume and low cost sugar cane gives the country a competitive edge in the production of ethanol for export.

What also gives the country an edge is its scientific expertise. With $90 \%$ of the sugar cane genome sequenced in 2003, research groups, notably in the state of São Paulo, have been producing transgenic cane varieties with better productivity, resistance to drought and bad soils. Raul Fernandes, Industrial Director, Candura Sugar Trading, in Recife, emphasizes the constant search for new varieties of sugarcane with "higher overall sugar content, higher yield per hectare, greater longevity and resistance to diseases".

At the mills there is a gradual move from batch fermentation to continuous fermentation, which raises average efficiency from $88 \%$ to 90\%. Between 1978 and 2000, the average ethanol yield per hectare increased by $3.5 \%$ annually. When oil prices rise above $\$ 50$ dollars a barrel, ethanol starts to compete with oil, regardless of the impact on carbon emissions.

However, the logistics of distribution rather than productive capacity threatens to limit the expansion of Brazil's ethanol exports. Simplifying distribution means building ports with storage tanks and loading facilities, and improving railway and pipeline links between the ports and sugar-producing regions; 'ethanolducts' are being planned to help offset this problem. "The logistics are important because otherwise you end up using too much nonrenewable fuel to ship renewable fuels, which is inefficient," comments Raul Campos, director of investment relations at Petrobras, in Brasilia. A new ethanol port terminal in Santos will increase Brazil's export capacity to 5.6 billion liters by the end of 2006 .

Until recently Brazilian ethanol has been produced for domestic consumption, with only a fraction being exported. But in 2004 exports more than doubled to 2.6 billion liters, representing over 1\% of Brazil's total exports. In 2005 the futures market for sugar rose by $62 \%$ on the back of rising international demand for ethanol. Brazil currently exports ethanol to the US, India, Venezuela and Nigeria. Demand from China and European countries is expected to grow over the coming years. "Petrobras anticipates exports of 8 billion liters in 2010, by which it is estimated that total production will have reached 26 billion liters," says Paes de Carvalho.

In the short to medium term Brazil is the only country capable of sustaining a burgeoning international ethanol market. "Conservative estimates suggest that the area for sugarcane production could double from 5.7 to 11 million hectares in the next ten years," notes Fernandes.

The expansion of the ethanol fuel business is not safe from occasional crises, however, according to economist Eduardo Pereira de Carvalho, head of the Sugarcane Agro Industry Union of the State of São Paulo, which produces around $80 \%$ of the ethanol. Indeed, he explains, "There will be moments when the evolution of supply will overcome that of markets, and we will also see situations when growth will be insufficient to deal with all [the] demand."

In practice, market growth might also be restrained by the reluctance of importing countries to depend on a single provider. For an international market to take root in the long term, other sugar-producing countries like Australia, Colombia, Guatemala, India, Mexico and Thailand will need to expand their exports. They too could develop their own biotech sector through this type of industrial biotech application. And Brazil is crafting deals to help other countries gear up their biofuel programs.

Paulo Strini, Commercial Manager, SCA Trading, São Paulo, argues that it is in Brazil's interest to share technology with other producer countries. "Brazil has natural advantages such as available land and favorable climate, especially the copious rainfall needed to produce sugarcane. It is a mistake for Brazil to think that Brazil alone should produce ethanol for the whole world. If we want to benefit from a dependable futures market it is necessary for other producers to be opening up markets."

Claudia Orellana, Brecon, UK Additional reporting, Ricardo Bonalume Neto, São Paulo, Brazil 